\title{
Student Satisfaction towards the Personalization of Appearance in Online Learning Environments ${ }^{*}$
}

\author{
Irfan SURAL \\ Eskisehir Osmangazi University, Eskisehir, Turkey \\ Müjgan BOZKAYA \\ Anadolu University, Eskisehir, Turkey
}

\begin{abstract}
In this study, personalization of online learning environments, learner participation, and satisfaction in using these environments are inquired. With this purpose in mind, learners' personalization preferences of appearance and their satisfaction regarding the personalization in online learning environments are determined. In data collection and analysis processes, both quantitative and qualitative methods were used. And the study was designed as an explanatory mixed method research. Data is collected from 60 second-year students registered to Instructional Design Course in Computer and Instructional Technology in Education Department in Faculty of Education at Eskisehir Osmangazi University, Eskisehir, Turkey. In the study, to test the difference between two means, independent samples $t$-test was carried out but among non-parametric methods, and Mann-Whitney $U$ test was conducted, because the normality hypothesis was not obtained in the tests. In order to evaluate students' learning environment usage and personalization of appearance satisfaction, survey was provided. Moreover, focus group discussions and in-depth interviews were held with the students chosen among both the ones who fulfilled the personalization and the ones who did not. According to the results of the study, satisfaction level of the ones who did the personalization was higher than the ones who did not.
\end{abstract}

Keywords: personalization, online learning, distance education, satisfaction, learning management system

\section{Introduction}

Today, the rapid developments in the field of information and communication technology have become the most important dynamics of the situation of social change. Having not been limited within its own field, its changes and developments also affect the education system as it affects all other fields. Learning environments, which are set to accomplish educational facilities, have been rapidly continuing to change. With the rapid advancements and innovations in technology, educational policies of Turkey have been structured on bringing up individuals who are "learning to learn," providing the individuals with an environment in which they educate themselves whenever and wherever available to them, and even enabling them to learn according to their knowledge level and learning skills (Turkish Foundation for Science, 2003). One way to accomplish this

\footnotetext{
* This study is prepared as a part of dissertation "The Relationship of Personalization with Learner Performance and Satisfaction Level in Online Learning” with advisor Dr. Müjgan BOZKAYA.

Irfan SURAL, Dr., assistant professor, Computer Education and Instructional Technology Department, Faculty of Education, Eskisehir Osmangazi University.

Müjgan BOZKAYA, Dr., professor, Distance Education Department, Faculty of Open Education, Anadolu University.
} 
is distance education. Distance education provides the tools necessary to meet the growing learning needs and makes learning independent of time and space. Online learning is defined as a type of distance education, which is designed to be delivered through Web, which provides independent of time and place access, and which is facilitated over a net (Internet or Intranet) (Horton, 2000). The concept of Web 2.0 is a new generation of the Web in which users have leading role and content is more important than design. With the development of the technologies in online learning environments, it is possible for learners to edit their own learning environments and personalize them for their needs.

\section{Literature Review}

There are some studies in the literature which explain how people personalize their offices (Brunia \& Hartjes-Gosselink, 2009; Wells, Thelen, \& Ruark, 2007; Wells, 2000), their isolated areas like the ones in the poles (Evans \& Carrere, 1994), their dormitory rooms (Vinsel, Brown, Altman, \& Carolyn, 1980), and patient rooms (Holahan \& Saegert, 1973). Similarly, personalization on mobile phones that surround our lives, computers, and electronic products are taking place, and research articles on personalization of learning environment continue to increase day by day. Although there is no consensus on the definition of personalization in the literature, there are many terms used as a synonym for it, such as customization, classification (Smith, 1956), mass customization (Pine, 1993), individualization (Riemer \& Totz, 2001), targeting, profiling, direct targeting (Peppers \& Rogers, 1997), and so on. The term personalization, which is used in a wide area ranging from the customization of life space to the customization of technological devices and environments, has been defined as a process that changes the functionality, interface, information content, or distinctiveness of a system to increase its personal relevance to an individual (Blom, 2000). In the study for the personalization of desktop and mobile phones, Blom and Monk (2003) studied the effects of personalization process on the users in many aspects, and these aspects grounded the Theory of Personalization of Appearance. In a study towards the personalization of the mobile phones and desktops, impact of personalization on users was considered in many aspects. There are two main categories in the Theory of Personalization of Appearance. One is "dispositions to personalize appearance" and the other is "effects of personalization on the user" (Blom \& Monk, 2003). Accordingly, categories like the frequency of use of the system or product, ownership of the system or environment, knowledge of personalization, ease of personalization, effectiveness of personalization features, and socioemotional context of use affect the dispositions to personalize appearance. However, ease of use, improved aesthetics, recognition of system, reflection of personal identity, familiarity with system etc. are components of the effects of personalization on the user. The personalization of desktop and mobile phones, which are the subjects of the Theory of Personalization of Appearance, and portal sites like Yahoo (Ho, 2006), Gmail and Hotmail, email accounts, wiki and blog pages and similar Web 2.0 tools, have taken place among the environments in which personalization can be done and all these developments together lead to personalization in learning environments.

Personalization can be either user-initiated or system-initiated. In user-initiated personalization, the user himself manipulates aspects of his device or system or configures contents of a Website based on his individual needs and wants. On the contrary, in the system-initiated personalization, the system/device adapts content using information about the user or his/her behavior captured by the system/device. In the literature, studies on personalization of the Web applications have generally focused on determining and outlining the aspects of personalization (Fan \& Poole, 2006; Miceli, Ricotta, \& Costabile, 2007; Palmér, Sire, Bogdanov, Gillet, \& 
Wild, 2009) and the customization of the user profiles (Bouzeghoub \& Kostadinov, 2006), and showing service, news, content, and ads according to the users interest (Lavie, Sela, Oppenheim, Inbar, \& Meyer, 2010). Troyer and Leune (1998) dealt with problems related to personalization design, and "Website design method (WSDM)" was discussed and focused on user-driven web applications. In this study, possible user profile information is systematically collected, class diagrams are constructed, and various navigation options are created in the web pages without considering the individual differences. In another two interesting studies on personalization (Ceri, Fraternali, \& Paraboschi, 1999; Ceri, Fraternali, \& Bongio, 2000), user- or groupfocused presentation of the Web sites is conducted by using the Web modeling language (Web ML). Purchase history and favorite sites of individual users with extensible markup language (XML)-based schemas are being collected and associated with the user's data. A similar study of Ceri et al. (2000) was conducted by Rossi, Schwabe, and Guimarães in 2001. However, instead of Web ML, which is data-centered, an object-oriented hypermedia design method approach was used. In this approach, it is possible to use different content and design templates for different access levels. In a study, Martinez and Bunderson (2007) pointed out that there exists a relationship between the individual's learning style and personalizable environments, and added that learning takes place more successfully if designs that consider the individual characteristics of the learner are applied. It is also pointed out that when general design principles are applied, learning failures might occur and from this aspect, designs, which consider individual differences, should be offered in online learning environments. Another research study on interactive and personalizable design of online learning environment was conducted by Granlie and MacQuarrie (2008). Project that was funded by European Union carried out in four institution located in Denmark and Germany, designed online virtual museum considering learner needs, learning styles, and profile information. Users can also choose text size preferences and the way they navigate by selecting text-based or visual-based navigation.

In the literature, although there are studies suggesting that the design of the websites consider the user demands, it can be said that the use of these environments for educational purposes and studies on enabling the personalization according to the personal preferences of learners is new. Similarly, studies on the personalization of appearance like font type, color, and background color in online learning environments are very rare. In a study, Blom and Monk (2007) stated that users generally personalized the elements, such as background images, graphics, profile pictures, and font color in the web environments provided. Liang, Lai, and $\mathrm{Ku}$ (2007) stated that personalization can reduce overload of information, and thus, it will increase the user satisfaction.

In assessing the effectiveness of the learning activities in online learning environments, various methods are used. The most common method is satisfaction and performance (Martinez-Caro, 2009). Structure and design of the course have a key role in the learner satisfaction in online learning (Roach \& Lemasters, 2006). While learner satisfaction has increased its importance day by day as the most effective factors of online programs (Holder, 2007; Ginns \& Ellis, 2007; Kim, Liu, \& Bonk, 2005), studies on online learning should be the ones that should reinforce the present aspects, contribute new aspects, or make up deficiencies in this field. Some studies pointed out that learners' being familiar with technology use and their attitudes towards online learning systems affect learner satisfaction (Changchit, 2007; Hammoud, Love, Baldwin, \& Sherry, 2008; Liu, Teh, Peiris, \& Choi, 2009), and learners with higher computer use experience are more satisfied with online learning (Liu et al., 2009). However, traditional online applications, which provide content with the same design for all users, have remained insufficient in providing satisfaction to students. 


\section{Methodology}

The purpose of this paper is to study the relationship between the personalization of appearance and learner satisfaction level in online learning environments. In data collection and analysis processes with regards to answer research questions, both qualitative and quantitative methods were used and therefore the study is designed as a mixed model. In the mixed model research, qualitative and quantitative approaches, methods, concepts, or techniques are used together, and in some phases, both qualitative and quantitative data are collected, analyzed, or combined to have a better understanding of the problem (Creswell, 2008; Gay, Mills, \& Airasian, 2006; Johnson \& Christensen, 2008; Johnson \& Onwuegbuzie, 2004). Mixed model research use both types of data when quantitative- or qualitative- only data is insufficient in exploring research questions. Mixed research method aims to minimize the weaknesses of the use of other methods. Therefore, the quality of the research carried out by using mixed methods, which use strong side of both quantitative and qualitative, is increasing (Creswell, 2008; Johnson \& Christensen, 2008). Participants of the study were 60 students who were registered to Instructional Design Course at Eskisehir Osmangazi University, Faculty of Education, Computer and Instructional Technology in Education Department in 2010-2011 Spring term. The reason for choosing this course is its modular structure and being suitable for the online learning environment developed for use in this study.

\section{Data Collection}

Data was collected in three phases: before, during, and after the implementation. Before the implementation, data were obtained from personal information questionnaire; during the implementation, the usage statistics were obtained from personalizable learning management system (LMS); and after the implementation, based on the evaluation questionnaire of the environments, focus group and in-depth interviews were analysed.

\section{Personalizable LMS}

An account to access the environment was created for each student and given to them in the beginning of the course by the researcher. Personalizable LMS that is provided to students contains learning content materials and functionality to personalize student's learning environment. Personalized profile, preferences, and main menu contain modules, blog, wiki, resources, chat, and email tools that are listed at left side of page as seen in Figure 1.

The course content, which was prepared by the course facilitator and consisted of three modules, was digitized and uploaded to LMS by the researcher. In the first module, personalization was not enabled for the students. In the second module, students were able to personalize both the order of the content and visual elements like font type, size, text color, and background color throughout the Web based learning environment. In the third and last module, students were allowed to change only visual elements like font type, size, text color, and background color (see Figure 2).

Students are able to personalize their learning environment online. Therefore, no external administer pages or redirection is used.

\section{Personalizable LMS Usage Statistics}

In the study, the main data collection source is the personalizable LMS specially developed for this study. In order for students to access from anywhere, www.ogretimtasarimi.net domain name was allocated and the personalizable LMS was configured by the researcher. Each user activity like time spent on page, click count, 
referrer addresses, personalization preferences, and the frequency of the preference-changing are recorded into database for each user.

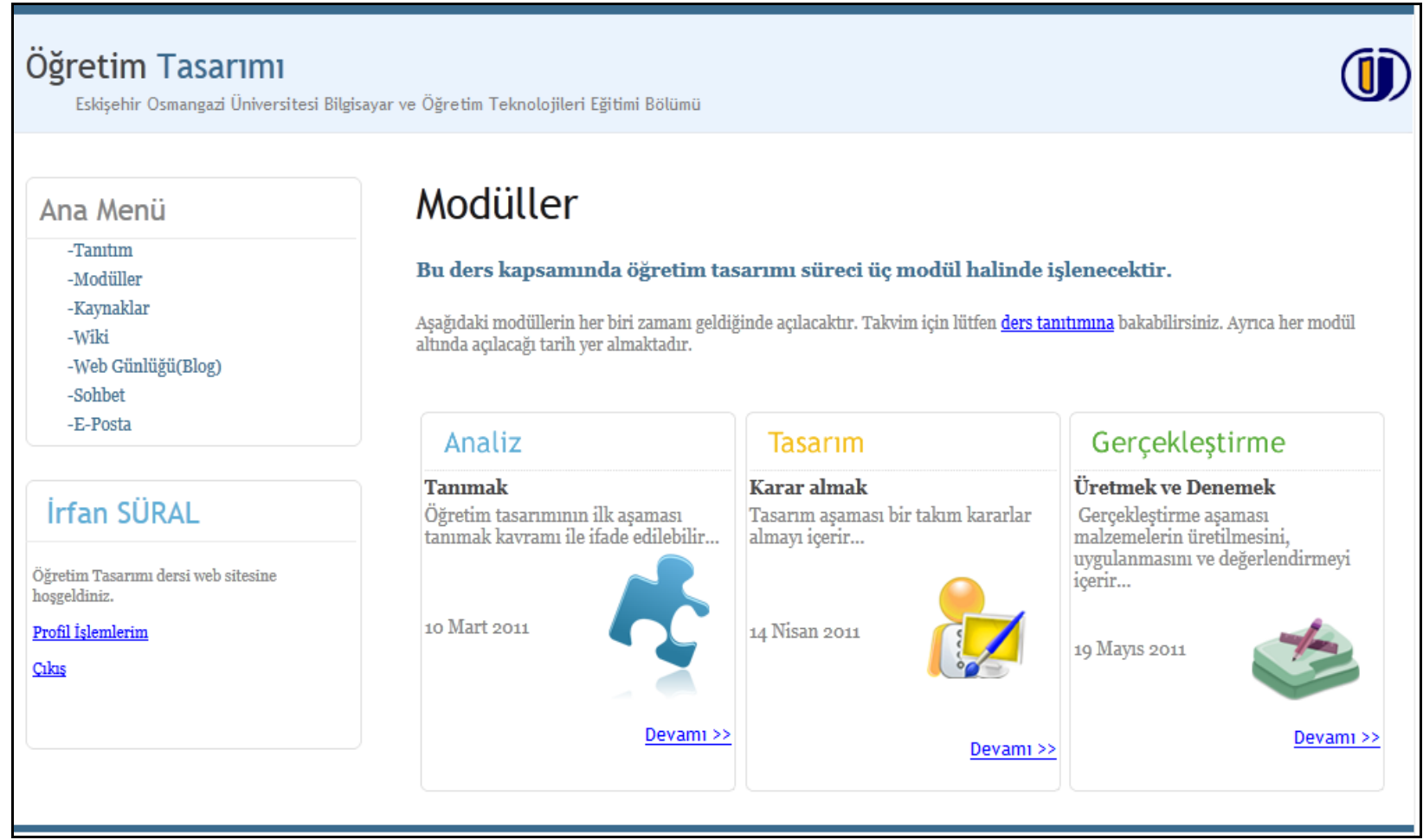

Figure 1. Personalizable LMS.

\begin{tabular}{|c|c|c|c|}
\hline \multicolumn{4}{|l|}{ Ana Menü Kişiselleștirme Ekranı } \\
\hline \multirow{2}{*}{\multicolumn{4}{|c|}{ Ana Menü }} \\
\hline -Tanitım & & & \\
\hline -Modüller & Renk Değiştir & Yazı Tipi Değiştir & Yazı Boyutu Değiştir \\
\hline -Kaynaklar & & & \\
\hline -Wiki & & & \\
\hline -Web Günlüğü(Blog) & & & \\
\hline -Sohbet & & & \\
\hline -E-Posta & & & \\
\hline \multicolumn{4}{|c|}{$\begin{array}{l}\text { Sayfadaki renk değisisikliğini görmek için Lütfen renk seçimini yaptıktan sonra "Seç.." düğmesi üzerine tekrar } \\
\text { geliniz. Tüm sekmelerdeki ayarlamaları bitirdiğinizde Ayarları Kaydet'e tıklayarak ișleminizi bitirebilirsiniz. } \\
\text { Ayarları sıfirla orjinal ayarlara geri döndürür. }\end{array}$} \\
\hline Ana Menü Arka Plan Rengi: \#99CCFF & Seç... & & \\
\hline Ana Menü Başlık Yazı Rengi: \#828282 & Seç... & & \\
\hline \multirow[t]{2}{*}{ Ana Menü Bağlantı Yazı Rengi: \#3d6f91 } & Seç... & & \\
\hline & Ayarlan Kaydet & Ayarlan Sifirla & \\
\hline
\end{tabular}

Figure 2. Web tool to personalize appearance.

\section{Personal Information Questionnaire}

Personal information questionnaire was designed to get information, such as gender, experience of the Internet and computer use, status of access to technology and its use, status of customizing Web 2.0 tools, and 
attitudes toward online learning environments of the students who were registered to instructional design course. Participants were firstly asked to fill out this form in the study.

\section{Environment Evaluation Questionnaire}

Within the scope of the study, in the environment evaluation questionnaire, which was designed to assess satisfaction, every question was responded by giving points ranging from seven (finding very useful) to one (never finding useful). In this questionnaire, there were questions about the way the course carried out, Web 2.0 tools used in the course, and the tools in the personalizable learning environment.

\section{Focus Group Discussion}

In the focus group discussions, 29 out of 60 students who participated in the first phase of the study were interviewed in four different group discussions. In LMS, learner's data from four environments were analyzed. These include personalization of the appearance, order of content personalization, wiki environment, and blogs. As a result of the analysis, students were divided into four categories according to the ones who personalized the four environments, the ones who personalized the three environments, the ones who personalized the two environments, and the ones who personalized only one environment.

\section{Validity and Reliability of the Study}

The codes obtained during the focus group discussions and in-depth interviews were analyzed by the experts, together with themes and the subjects on which "agreed" and "disagreed" were discussed and necessary changes were made afterwards. For reliability estimation, the following convergent percentage suggested by Miles and Huberman (1994) was used. In the estimation done by using the convergent percentage formula of Miles and Huberman, reliability of the focus group discussions was found.

\section{Findings}

\section{Findings of Two Earlier Phases}

The participants enrolled in the study, 31 (51.7\%) were male and 29 (48.3\%) were female. The class distribution of the participants, 42 (70\%) were 2nd grade and 13 (21.7\%) 1st grade students (see Table 1).

Table 1

Descriptive Statistics of Participants

\begin{tabular}{lll}
\hline Gender & $f$ & Percentage (\%) \\
\hline Male & 31 & 51.7 \\
Female & 29 & 48.3 \\
\hline
\end{tabular}

As a result of Mann-Whitney analysis, which was done to study whether there exists a difference in participants' general course satisfaction according to using the personalization of the appearance facilities, no statistical difference was found between the participants who personalized the appearance and the ones who did not in the context of the subject studied (Mann-Whitney $U=338.5, Z=-0.243, p>0.05$ ) (see Table 2).

Similarly, as a result of Mann-Whitney analysis, which was done to study whether there exists a difference in participants' satisfaction for personalization according to using the personalization of the appearance facilities, no statistical difference was found between the participants who personalized the appearance and the ones who did not in the context of the subject studied (Mann-Whitney $U=261.5, Z=-1.628, p>0.05$ ) (see Table 3). 
Table 2

The Relationship Between the Personalization of Appearance and Learner Satisfaction Level

\begin{tabular}{lllllll}
\hline & \multicolumn{7}{c}{ General course satisfaction } \\
\cline { 2 - 7 } & & $f$ & $\overline{\mathrm{X}}$ & SS & $Z$ & $p$ \\
\hline \multirow{2}{*}{ Personalization of appearance } & Yes & 32 & 5.72 & 0.75 & -0.243 & 0.808 \\
& No & 22 & 5.68 & 0.73 & & \multirow{2}{*}{0.73} \\
\hline
\end{tabular}

Table 3

The Relationship Between the Personalization of Appearance and Satifaction on Personalization of Appearance

\begin{tabular}{lllllll}
\hline & \multicolumn{7}{c}{ Satisfaction on personalization of appearance } \\
\cline { 2 - 7 } & & $f$ & $\bar{X}$ & SS & $Z$ & $p$ \\
\hline \multirow{2}{*}{ Personalization of appearance } & Yes & 32 & 6.09 & 1.17 & \multirow{2}{*}{-1.628} & 0.104 \\
\hline
\end{tabular}

On the other hand, in the analysis done between the students' average of personalization frequency and average of satisfaction in personalizing the appearance, there was a meaningful relationship $(r=0.340, p<$ 0.05). However, there existed no significant difference between the students' average of personalization frequency and average scores for satisfaction of the course ( $r=0.159, p>0.05)$. While when overall satisfaction averages are analyzed, it can be said that participants were generally satisfied with with the course. Besides, personalization satisfaction of the participants who carried out personalization was higher than the ones who did not (see Table 4).

Table 4

The Relationship Between Average of Personalization Frequency and Satisfaction in Personalizing the Appearance/Satisfaction of the Course

\begin{tabular}{llrr}
\hline & & \multicolumn{2}{c}{ Correlations } \\
\cline { 2 - 4 } & & \multicolumn{2}{c}{ Students' average of personalization frequency } \\
\hline Satisfaction of the course & $f$ & $r$ & $p$ \\
Satisfaction in personalizing the appearance & 54 & 0.159 & 0.250 \\
\hline
\end{tabular}

\section{Findings of Last Phase}

Some of the participants finding the personalization activity enjoyable stated that they had fun during this process.

Participant 21: “... I find it very enjoyable. I mean, in the past we could not do it any sites we visited. We were using them as they were presented. But now, as I said, I like changing there because it is functional.”

Participant 28: “... It is very enjoyable. Behold, so all you are doing something new. You are redesigning something that happens very enjoyable.”

Participant 19: “... Sounds fun.”

One of the participants stated that being able to personalize the environments as she/he wishes motivated her/him.

Participant 25: “All in all, you find something specific, you see as you want to see. I think this is motivating."

Some of the participants indicated their satisfaction for personalizing the appearance and that they liked doing this.

Participant 29: "I tried hard but I like designing. I even thought it would be very good if there were images and I 
could insert them. I liked it, it was good; then I pressed apply and I wondered whether it would really work. I pressed and the color changed, I was happy, I mean it felt good."

\section{Conclusion}

When analyzing the relationship between the states of using the facilities provided for personalization and satisfaction level, there was no significant difference. Still, in the focus group discussions and in-depth interviews, students generally indicated their satisfaction for the methodology of the course, learning environment, and personalization tools. Moreover, satisfaction level of the participants who personalized the appearance and content order was higher than the ones who did not. This finding is supported by the studies in the literature. In a study, Chang and Chen (2008) advocated that content and interface personalization would provide a higher customer satisfaction. According to Kwon and Kim (2012), user based personalization is more effective than system-based personalization in terms of customer satisfaction. Similarly, in another study in which different personalization strategies were used, it was found out that more than half of the participants were content with personalization process (Essalmi, Ayed, Jemni, \& Graf, 2010). Participants also stated that they did not encounter any technical problem in the personalization process, but they suggested that it would be better to improve the personalization tools, so that facilities like adding a profile picture, applying design templates, and audio visual or text-based content presentation according to learning styles could be presented in a more wide range.

\section{References}

Blom, J. (2000). Personalization-A taxonomy. Extended abstracts of the CHI 2000 Conference on Human Factors in Computing Systems (pp. 313-314). New York: ACM.

Blom, J. O., \& Monk, A. F. (2003). Theory of personalization of appearance: Why users personalize their PCs and mobile phones. Human-Computer Interaction, 18(3), 193-228.

Blom, J. O., \& Monk, A. F. (2007). A theory of personalisation of appearance: Quantitative evaluation of qualitatively derived data. Behaviour \& Information Technology, 26(3), 237-246.

Bouzeghoub, M., \& Kostadinov, D. (2006). Data personalization: A taxonomy of user profiles knowledge and a profile management tool. Retrieved December 20, 2009, from http://citeseerx.ist.psu.edu/viewdoc/download?doi=10.1.1.100.4831 \&rep=rep1\&type=pdf adresinden alındı

Brunia, S., \& Hartjes-Gosselink, A. (2009). Personalization in non-territorial offices: A study of a human need. Journal of Corporate Real Estate, 11(3), 169-182.

Ceri, S., Fraternali, P., \& Bongio, A. (2000). Web modeling language (Web ML): A modeling language for designing Web sites. Proceedings of the Ninth International World Wide Web Conference (pp. 137-157). Netherlands: Elsevier.

Ceri, S., Fraternali, P., \& Paraboschi, S. (1999). Data-driven one-to-one Website generation for data-Intensive applications. Proceedings of the 25th VLDB Conference (pp. 615-626). Edinburgh, Scotland.

Chang, H. H., \& Chen, S. W. (2008). The impact of customer interface quality, satisfaction, and switching costs on e-loyalty: Internet experience as a moderator. Computers in Human Behavior, 24, 2927-2944.

Changchit, C. (2007). An exploratory study on students' perceptions of technology used in distance learning environment. Review of Business Research, 7(4), 31-35.

Creswell, J. W. (2008). Educational research: Planning, conducting, and evaluating quantitaive and qualitative research (3rd ed.). New Jersey: Pearson Education, Inc.

Essalmi, F., Ayed, L. J., Jemni, M., \& Graf, S. (2010). A fully personalization strategy of E-learning scenarios. Computers in Human Behavior, 26(4), 581-591.

Evans, G. W., \& Carrere, S. (1994). Life in an isolated and confined environment: A qualitative study of the role of the designed environment. Environment and Behavior, 26(6), 707-741.

Fan, H., \& Poole, M. S. (2006). What is personalization? Perspectives on the design and implementation of personalization in information systems. Journal of Organizational Computing and Electronic, 16(3), 179-202. 
Gay, L. R., Mills, G. E., \& Airasian, P. W. (2006). Educational research: Competencies for analysis and applications (8th ed.). New Jersey: Pearson Education.

Ginns, P., \& Ellis, R. (2007). Quality in blended learning: Exploring the relationships between on-line and face-to-face teaching and learning. Internet and Higher Education, 10(1), 53-64.

Granlie, J., \& Macquarri, K. (2008). Interactive and customizable learning environments for various user needs: Danish-German virtual museum project. Retrieved November 29, 2009, from http://www.archimuse.com/mw2008/papers/ granlie/granlie.html

Hammoud, L., Love, S., Baldwin, L., \& Sherry, C. Y. (2008). Evaluating Web ct use in relation to students' attitude and performance. International Journal of Information and Communication Technology Education, 4(2), 26-43.

Ho, S. Y. (2006). The attraction of internet personalization to Web users. Electronic Markets, 16(1), 41-50.

Holahan, C. J., \& Saegert, S. (1973). Behavioral and attitudinal effects of large-scale variation in the physical environment of psychiatric wards. Journal of Abnormal Psychology, 82(3), 454-462.

Holder, B. (2007). An investigation of hope, academics, environment, and motivation as predictors of persistence in higher education online programs. Internet and Higher Education, 10(7), 245-260.

Horton, W. (2000). Designing Web-based training: How to teach anyone anything anywhere anytime. New York, USA: John Wiley \& Sons. Inc..

Johnson, R. B., \& Onwuegbuzie, A. J. (2004). Mixed methods research: A research paradigm whose time has come. Educational Researcher, 33(7), 14-26. Retrieved January 2, 2012, from http://www.aera.net/uploadedfiles/journals_and_publications/ journals/educational_researcher/volume_33_no_7/03erv33n7_johnson.pdf

Kim, K. J., Liu, S., \& Bonk, C. J. (2005). Online MBA students’ perceptions of online learning: Benefits, challenges, and suggestions. Internet and Higher Education, 8(4), 335-344.

Kwon, K., \& Kim, C. (2012). How to design personalization in a context of customer retention: Who personalizes what and to what extent? Electronic Commerce Research and Applications, 11(2), 101-116.

Lavie, T., Sela, M., Oppenheim, I., Inbar, O., \& Meyer, J. (2010). User attitudes toward news content personalization. International Journal of Human-Computer Studies, 68(8), 483-495.

Liang, T. P., Lai, H. J., \& Ku, Y. C. (2007). Personalized content recommendation and user satisfaction: Theoretical synthesis and empirical findings. Journal of Management Information Systems, 23(3), 45-70.

Liu, W., Teh, K. S., Peiris, R. L., \& Choi, Y. S. (2009). Internet-Enabled user interfaces for distance learning. International Journal of Technology and Human Interaction (IJTHI), 5(1), 51-77.

Martinez, M., \& Bunderson, C. V. (2007). Foundations for personalized Web learning environments. Retrieved November 28, 2009, from http://www.sloan-c.org/publications/magazine/v4n2/burdenson.asp

Martinez-Caro, E. (2009). Factors affecting effectiveness in E-learning: An analysis in production management courses. Computer Applications in Engineering Education, 19(3).

Miceli, G. N., Ricotta, F., \& Costabile, M. (2007). Customizing customization: A conceptual framework for interactive personalization. Journal of Interactive Marketing, 21(2), 6-25.

Miles, M. B., \& Huberman, A. M. (1994). An expanded sourcebook qualitative data analysis (2nd ed.). California: Sage Publications Inc..

Palmér, M., Sire, S., Bogdanov, E., Gillet, D., \& Wild, F. (2009). Mapping Web personal learning environments. Proceedings of the MUPPLE' 09 Workshop at the European Conference for Technology Enhanced Learning, Nice, France.

Peppers, D., \& Rogers, M. (1997). The one-to-one future: Building relationships one customer at a time. New York: Double Day Publications.

Pine, J. B. (1993). Mass customization: The new frontier in business competition. Boston, M.A.: Harvard Business School Press.

Riemer, K., \& Totz, C. (2001). The many faces of personalization. Proceedings of the 2001 World Conference on Mass Customization and Personalization, Hong Kong University of Science and Technology.

Roach, V., \& Lemasters, L. (2006). Satisfaction with online learning: A comparative descriptive study. Journal of Interactive Online Learning, 5(3), 317-332.

Rossi, G., Schwabe, D., \& Guimarães, R. M. (2001). Designing personalized Web applications. Tenth International World Wide Web Conference, Hong Kong, China.

Smith, W. (1956). Product differentiation and market segmentation as alternative marketing strategies. Journal of Marketing, 21(1), 3-8.

Troyer, D., \& Leune, C. J. (1998). WSDM: A user-centered design method for Websites. Proceedings of the 7th International World Wide Web Conference (pp. 85-94). Netherland: Elsevier. 
Turkish Foundation for Science. (2003). Distance Education Report. Ankara. Retrieved December 11, 2011, from http://www.tbv.org.tr/Sayfa.aspx?ID=39

Vinsel, A., Brown, B., Altman, I., \& Carolyn, F. (1980). Privacy regulation, territorial displays, and effectiveness of individual functioning. Journal of Personality and Social Psychology, 39(6), 1104-1115.

Wells, M. M. (2000). Office clutter or meaningful personal displays: The role of office personalization in employee and organizational well-being. Journal of Environmental Psychology, 20(3), 239-255.

Wells, M. M., Thelen, L., \& Ruark, J. (2007). Workspace personalization and organizational culture: Does your workspace reflect you or your company? Environment and Behavior, 39(5), 616-634. 